\title{
CSF inflammatory markers differ in gram- positive versus gram-negative shunt infections
}

\author{
Gwenn L. Skar ${ }^{1 *}$ D, David Synhorst ${ }^{2}$, Matthew Beaver ${ }^{1}$ and Jessica N. Snowden ${ }^{3}$
}

\begin{abstract}
Background: Cerebrospinal fluid (CSF) shunt placement is frequently complicated by bacterial infection. Shunt infection diagnosis relies on bacterial culture of CSF which can often produce false-negative results. Negative cultures present a conundrum for physicians as they are left to rely on other CSF indices, which can be unremarkable. New methods are needed to swiftly and accurately diagnose shunt infections. CSF chemokines and cytokines may prove useful as diagnostic biomarkers. The objective of this study was to evaluate the potential of systemic and CSF biomarkers for identification of CSF shunt infection.
\end{abstract}

Methods: We conducted a retrospective chart review of children with culture-confirmed CSF shunt infection at Children's Hospital and Medical Center from July 2013 to December 2015. CSF cytokine analysis was performed for those patients with CSF in frozen storage from the same sample that was used for diagnostic culture.

Results: A total of 12 infections were included in this study. Patients with shunt infection had a median C-reactive protein (CRP) of $18.25 \mathrm{mg} / \mathrm{dL}$. Median peripheral white blood cell count was $15.53 \times 10^{3}$ cell $/ \mathrm{mL}$. Those with shunt infection had a median CSF WBC of 332 cells $/ \mathrm{mL}$, median CSF protein level of $406 \mathrm{mg} / \mathrm{dL}$, and median CSF glucose of $35.5 \mathrm{mg} / \mathrm{dL}$. An interesting trend was observed with gram-positive infections having higher levels of the anti-inflammatory cytokine interleukin (IL)-10 as well as IL-17A and vascular endothelial growth factor (VEGF) compared to gram-negative infections, although these differences did not reach statistical significance. Conversely, gram-negative infections displayed higher levels of the pro-inflammatory cytokines IL-1 $\beta$, fractalkine $\left(\mathrm{CX}_{3} \mathrm{CL}_{1}\right)$, chemokine ligand 2 (CCL2), and chemokine ligand 3 (CCL3), although again these were not significantly different. CSF from gram-positive and gram-negative shunt infections had similar levels of interferon gamma (INF- $\gamma$ ), tumor necrosis factor alpha (TNF-a), IL-6, and IL-8.

Conclusions: This pilot study is the first to characterize the CSF cytokine profile in patients with CSF shunt infection and supports the distinction of chemokine and cytokine profiles between gram-negative and gram-positive infections. Additionally, it demonstrates the potential of CSF chemokines and cytokines as biomarkers for the diagnosis of shunt infection.

Keywords: Shunt infection, Biomarker, Inflammation, Ventriculoperitoneal catheter, CSF cytokines

\footnotetext{
* Correspondence: gskar@unmc.edu

${ }^{1}$ Department of Pediatrics, University of Nebraska Medical Center, 982162

Nebraska Medical Center, Omaha, NE 68198-2162, USA

Full list of author information is available at the end of the article
}

(c) The Author(s). 2019 Open Access This article is distributed under the terms of the Creative Commons Attribution 4.0 International License (http://creativecommons.org/licenses/by/4.0/), which permits unrestricted use, distribution, and reproduction in any medium, provided you give appropriate credit to the original author(s) and the source, provide a link to the Creative Commons license, and indicate if changes were made. The Creative Commons Public Domain Dedication waiver (http://creativecommons.org/publicdomain/zero/1.0/) applies to the data made available in this article, unless otherwise stated. 


\section{Background}

Cerebrospinal fluid (CSF) shunts are the most common treatment of hydrocephalus in the USA; however, they are frequently complicated by bacterial infection [1]. Shunt infections are responsible for approximately 2400 admissions and 59,000 hospital days annually in the USA [2]. Bacteria cause the majority of shunt infections, with Staphylococcus epidermidis and Staphylococcus aureus among the leading causes [3-6]. Apart from staphylococci, Propionibacterium acnes, enterococci, and a variety of gram-negative bacteria including Pseudomonas aeruginosa and Escherichia coli commonly cause shunt infections [3-7].

Shunt infections present unique diagnostic and treatment challenges, since they are biofilm rather than planktonic infections [8]. Bacteria adhere to the catheter and form a biofilm, communities of bacteria which are tolerant to antibiotics and actively avoid immune clearance [9]. Thus, the inflammatory response to biofilm infection is distinct from planktonic infection, such as bacterial meningitis or intracranial abscess [9-12]. Due to their biofilm nature, shunt infection treatment requires both removal of the infected shunt and days or weeks of intravenous antibiotics [13]. With the extensive nature of treatment, it is essential that shunt infections are diagnosed accurately and rapidly.

While newer DNA-based detection methods are being instituted in the clinical microbiology laboratory, the gold standard method to diagnose shunt infection currently relies on isolating a pathogen from CSF culture [13-19]. While DNA sequencing methods for microbiological diagnosis are promising, they also have pitfalls, particularly in the case of shunt infection where many sequenced pathogens are common skin flora. The utility of broad-range polymerase chain reaction (PCR) may be limited by contamination with skin flora during collection and handling as well as antibiotic administration before a diagnosis is made [16]. The only multiplex PCR panel that is currently commercially available for meningitis/encephalitis has a limited spectrum of bacterial organisms, which is too narrow to be diagnostically useful for cerebrospinal fluid shunt infections, where Staphylococcus epidermidis and Staphylococcus aureus are the predominant organisms that are not included in this panel [3-6].

Traditional CSF culture normally requires $24-48 \mathrm{~h}$ to isolate organisms, and some slower growing organisms may require several days of incubation, which can delay appropriate treatment [20]. Additionally, if the patient has received antibiotics prior to the CSF culture, the culture may be falsely negative. In these cases, a clinician must rely on CSF indices such as cell count and differential, glucose, protein levels, and Gram stain, as well as clinical presentation, to determine if an infection is present [19]. A better modality to accelerate and accurately diagnose CSF shunt infections would improve our ability to treat these infections.

Identifying biomarkers in the CSF or serum of patients with shunt infection may improve our ability to diagnose CSF shunt infections. Biomarkers are distinct biochemical, genetic, or molecular substances that characterize infection [20, 21]. There are a few small studies that have evaluated the ability of CSF chemokines and cytokines to characterize different bacterial and viral meningitis. Many studies have examined the utility of using chemokines and cytokines for the diagnosis of meningitis. In early meningeal infection, the pro-inflammatory cytokines interleukin (IL)-8, IL-1, tumor necrosis factor alpha (TNF- $\alpha$ ), and IL- 6 have been shown to be elevated [22-25]. These mediators are released from CNS resident cells and function to recruit neutrophils and perpetuate the inflammatory response [26, 27]. Once monocytes are recruited, the anti-inflammatory cytokine IL-10 and IL-1 $\beta$ dampen inflammation by inhibiting production of pro-inflammatory cytokines [28].

Several studies have examined the possibility of using chemokines and cytokines as biomarkers for meningitis in the pediatric population. Elevated IL- 8 , IL- $1 \beta$, TNF- $\alpha$, and IL- 6 have routinely been shown to be elevated in bacterial meningitis [23-25, 29, 30]. Another study revealed that cytokines could be used to discriminate between meningitis caused by Streptococcus pneumoniae, Neiserria meningitidis, and Haemophilus influenzae based on levels of interferon gamma (IFN- $\gamma$ ), monocyte chemoattractant protein-1 (MCP-1), and the enzyme matrix metallopeptidase-9 (MMP-9) [31].

Studies by Srinivasan et al. [25] in neonates with meningitis have investigated the utility of cytokines as diagnostic markers in this population. They found that TNF- $\alpha$, IL-1, IL-6, IL-8, IL-10, and IL-12 levels were significantly elevated in infants with bacterial meningitis. However, none of these cytokines were considered sufficiently accurate for a differential diagnosis, which led to the examination of IL-23, IL-18, and soluble receptor for advanced glycation end products (sRAGE) in the same population [32]. The authors concluded that IL-23 might be a valuable biomarker for the diagnosis of neonatal bacterial meningitis and, when combined with IL-18 and sRAGE, diagnosed meningitis with $100 \%$ sensitivity and specificity [32]. Interestingly, relevant to the current report, of the 11 neonates with confirmed meningitis in these studies, there were 4 patients with ventriculoperitoneal shunts in place $[25,32]$.

To date, no study has examined CSF chemokine and cytokine expression exclusively in patients with CSF shunt infections. Animal models of shunt infection suggest that the inflammatory response in these biofilm infections may be attenuated in comparison to planktonic 
infections; thus, by extension, the same cytokine and chemokine responses may not be observed in shunt infections as in meningitis $[9,10,33-35]$. One study of shunt infection identified a possible role for soluble membrane attack complex in diagnosis of shunt infection, but this molecule was not able to identify many cases of S. epidermidis infection, which is the most common cause of shunt infection [36]. Therefore, to characterize potential biomarkers of CSF shunt infection, we evaluated systemic indicators of infection as well as CSF cytokines in a cohort of patients diagnosed with CSF shunt infection.

\section{Methods}

In this retrospective study, we included all patients less than or equal to 21 years of age with culture-confirmed bacterial CSF shunt infection diagnosed between July 1, 2013, and December 31, 2015, at Children's Hospital and Medical Center (CHMC) in Omaha, Nebraska. Patients were identified by International Classification of Disease, 9th revision coding, and confirmed by positive CSF culture results in accordance with the modified criteria for nosocomial infection of the US Centers for Disease Control and Prevention [15]. CSF culture was performed in the clinical microbiology laboratory at CHMC in accordance with the Clinical Microbiology Procedure Handbook [17]. CSF cell count, differential, glucose, and protein levels were assessed in the clinical laboratory at CHMC in accordance with Clinical \& Laboratory Standards Institute protocols $[37,38]$.

Patients were excluded if their diagnostic CSF culture was performed at another institution or grew yeast or if no CSF culture data was available. All participants were screened for additional inflammatory infection by medical chart review and were excluded if there was an additional inflammatory condition documented in the medical record that would alter inflammatory markers, such as a concomitant viral upper respiratory infection.

Data extracted from the patients' chart included the following: patient age, peripheral white blood cell (WBC) count, peripheral $C$ reactive-protein (CRP), CSF WBC count and differential, CSF glucose, CSF protein, and CSF culture results. Patient's peripheral WBC, CRP, CSF WBC and differential, CSF glucose, and CSF protein were included if they were obtained within a 48-h window from the time of the CSF culture.

For those patients with CSF in frozen storage from the same sample that was used for diagnostic culture, additional cytokine analysis was conducted. The CSF was analyzed by multiplex analysis for cytokines and chemokines (Millipore Milliplex Billerica, MA). The multiplex panels included the following: chemokine ligand 2 (CCL2), chemokine ligand 3 (CCL3), fractalkine
$\left(\mathrm{CX}_{3} \mathrm{CL}_{1}\right)$, vascular endothelial growth factor (VEGF), TNF- $\alpha$, IFN- $\gamma$, IL-1 $\beta$, IL-6, IL-8, IL-10, and IL-17A.

Descriptive statistics were performed using SigmaPlot. A $t$ test was used to compare mean cytokine levels in those patients with gram-positive shunt infection compared to those with gram-negative infection. This study was approved by the University of Nebraska Medical Center Institutional Review Board.

\section{Results}

A total of 11 individual patients with 12 separate shunt infections were included in this study (Table 1). Patient ages ranged from 5 weeks to 20 years with a median age of 4 months. All patients had a culture-confirmed ventriculoperitoneal shunt infection. Organisms identified from culture included the following: methicillin-resistant Staphylococcus aureus (1), viridans group streptococci (1), coagulase-negative staphylococci (2), Enterococcus faecalis (1), Gemella haemolysans (1), Serratia marcescens (1), Pseudomonas aeruginosa (2), Escherichia coli (1), Enterobacter cloacae (1), and Stenotrophomonas maltophilia (1).

Of the eight patients with CRP, the median was 18.25 $\mathrm{mg} / \mathrm{dL}(0.5-35.9 \mathrm{mg} / \mathrm{dL})$. All but one patient had a peripheral WBC count performed within $48 \mathrm{~h}$ of their CSF culture, and the median WBC was $15.53 \times 10^{3}$ cells $/ \mathrm{mL}$ $\left(5.97-29.71 \times 10^{3}\right.$ cells $\left./ \mathrm{mL}\right)$. Nine patients had CSF WBC within $48 \mathrm{~h}$ of their CSF culture with a median CSF WBC of 332 cells $/ \mathrm{mL}$ (24-1914 cells $/ \mathrm{mL})$. The gram-positive infections appeared to have a neutrophil predominance in the CSF while gram-negative infections had a more varied cellular differential. Eight patients had results for CSF protein and CSF glucose. CSF protein had a median value of $406 \mathrm{mg} / \mathrm{dL}(24-600 \mathrm{mg} / \mathrm{dL})$, and CSF glucose had a median value of $35.5 \mathrm{mg} / \mathrm{dL}$ (20-75 $\mathrm{mg} / \mathrm{dL})$.

Seven of the patients had CSF available for cytokine analysis; of these, three had gram-positive infections and four had gram-negative. While not statistically significant, an interesting trend was observed with CSF from patients with gram-positive infections having higher levels of the anti-inflammatory cytokine IL-10 (1321.17 $\mathrm{pg} / \mathrm{mL}$ vs $514.49 \mathrm{pg} / \mathrm{mL})$ as well as IL-17A $(193.95 \mathrm{pg} /$ $\mathrm{mL}$ vs $14.05 \mathrm{pg} / \mathrm{mL}$ ) and VEGF $(303.84 \mathrm{pg} / \mathrm{mL}$ vs 45.37 $\mathrm{pg} / \mathrm{mL}$ ) (Fig. 1). In contrast, the gram-negative group had increases in IL-1 $\beta(1522.76 \mathrm{pg} / \mathrm{mL}$ vs $179.79 \mathrm{pg} / \mathrm{mL})$ and numerous chemokines, including $\mathrm{CX}_{3} \mathrm{CL}_{1}(532.93$ $\mathrm{pg} / \mathrm{mL} \quad$ vs $187.95 \mathrm{pg} / \mathrm{mL}), \quad$ CCL2 $\quad(7094.50 \mathrm{pg} / \mathrm{mL} \quad$ vs $5741.00 \mathrm{pg} / \mathrm{mL})$, and CCL3 $(665.74 \mathrm{pg} / \mathrm{mL}$ vs $183.06 \mathrm{pg} /$ $\mathrm{mL})$ (Fig. 1). Levels of IFN $-\gamma(39.06 \mathrm{pg} / \mathrm{mL}$ vs $50.75 \mathrm{pg} /$ $\mathrm{mL}), \quad$ TNF- $\alpha$ (184.14 $\mathrm{pg} / \mathrm{mL}$ vs $215.41 \mathrm{pg} / \mathrm{mL})$, IL-6 $(5191.26 \mathrm{pg} / \mathrm{mL}$ vs $4816.35 \mathrm{pg} / \mathrm{mL})$, and IL-8 (3390.38 $\mathrm{pg} / \mathrm{mL}$ vs $2687.22 \mathrm{pg} / \mathrm{mL}$ ) were similar in both gram-negative and gram-positive infections (Fig. 1). 
Table 1 Patient age, CSF parameters, and CSF culture results

\begin{tabular}{|c|c|c|c|c|c|c|c|c|c|c|c|c|}
\hline \multirow[t]{2}{*}{$\begin{array}{l}\text { Patient } \\
\text { number }\end{array}$} & \multirow[t]{2}{*}{$\begin{array}{l}\text { Age } \\
\text { (months) }\end{array}$} & \multirow[t]{2}{*}{$\begin{array}{l}\text { CRP } \\
(\mathrm{mg} / \\
\mathrm{dL})\end{array}$} & \multirow[t]{2}{*}{$\begin{array}{l}\text { Peripheral } \\
\text { WBC } \\
\text { (cells/mL) }\end{array}$} & \multirow[t]{2}{*}{$\begin{array}{l}\text { CSF } \\
\text { WBC } \\
\text { (cells/ } \\
\mathrm{mL} \text { ) }\end{array}$} & \multicolumn{4}{|c|}{$\begin{array}{l}\text { CSF WBC } \\
\text { differential } \\
\text { (percentage) }\end{array}$} & \multirow[t]{2}{*}{$\begin{array}{l}\text { CSF protein } \\
(\mathrm{mg} / \mathrm{dL})\end{array}$} & \multirow[t]{2}{*}{$\begin{array}{l}\text { CSF glucose } \\
(\mathrm{mg} / \mathrm{dL})\end{array}$} & \multirow[t]{2}{*}{ CSF culture result } & \multirow[t]{2}{*}{$\begin{array}{l}\text { Cytokine analysis } \\
\text { performed }\end{array}$} \\
\hline & & & & & $\mathrm{N}$ & $\mathrm{L}$ & M & $\mathrm{O}$ & & & & \\
\hline 1 & 36 & 35.9 & 17.33 & NA & NA & & & & NA & NA & $\begin{array}{l}\text { Methicillin-resistant } \\
\text { Staphylococcus aureus }\end{array}$ & No \\
\hline 2 & 5 & NA & 18.26 & NA & NA & & & & NA & NA & Viridans group streptococci & No \\
\hline 3 & 8 & 5.1 & 9.63 & 1575 & 98 & 0 & 1 & 0 & 166 & 20 & Gemella haemolysans & No \\
\hline 4 & 3 & 17.4 & 8.54 & 985 & 99 & 1 & 0 & 0 & 600 & 21 & $\begin{array}{l}\text { Coagulase-negative } \\
\text { staphylococci }\end{array}$ & Yes \\
\hline 5 & 24 & NA & NA & 47 & 69 & 18 & 13 & 0 & 114 & 67 & $\begin{array}{l}\text { Coagulase-negative } \\
\text { staphylococci }\end{array}$ & Yes \\
\hline 6 & 240 & 8.9 & 29.71 & 377 & 86 & 6 & 8 & 0 & 600 & 75 & Enterococcus faecalis & Yes \\
\hline 7 & 1.25 & NA & 12.2 & NA & & & & & NA & NA & Enterobacter cloacae & No \\
\hline 7 & 3 & NA & 27.57 & 212 & 8 & 52 & 40 & 0 & NA & NA & Serratia marcescens & No \\
\hline 8 & 3 & 0.5 & 13.33 & 332 & 26 & 31 & 43 & 0 & 212 & 23 & Pseudomonas aeruginosa & Yes* $^{*}$ \\
\hline 9 & 3 & 19.1 & 15.57 & 1914 & 80 & 1 & 10 & 9 & 600 & 20 & Pseudomonas aeruginosa & Yes \\
\hline 10 & 84 & 27 & 12.73 & 24 & 8 & 21 & 68 & 3 & 24 & 61 & Stenotrophomonas maltophilia & Yes $^{*}$ \\
\hline 11 & 5 & 19.9 & 5.97 & 28 & 79 & 13 & 6 & 2 & 600 & 48 & Escherichia coli & Yes \\
\hline
\end{tabular}

CRP C-reactive protein, WBC white blood cell count, CSF cerebrospinal fluid, $N$ neutrophils, $L$ lymphocytes, $M$ monocytes, $O$ other cell type, $N A$ data not available *Not included in analysis for IFN- $\gamma$ of IL-17A

\section{Discussion}

Prompt diagnosis of shunt infection can allow for earlier treatment, including surgical intervention, potentially averting damaging consequences such as seizures and reduced IQ [39, 40]. However, CSF cultures may be negative due to prior antibiotic treatment or the difficulty of traditional culture in detecting biofilm infections. In these settings, clinicians are forced to use CSF indices and peripheral markers of inflammation to diagnose shunt infection. As observed in our cohort, peripheral leukocytosis is not always present in shunt infection and is very non-specific. CRP elevation was noted in our cohort and in others, but this has been inconsistent in other case studies [20, 21, 41]. CSF leukocytosis is a more specific measure for CSF infection and was observed in this group of patients. However, this can also occur in the setting of uninfected post-surgical inflammation, which presents a significant confounder as the post-surgical period is also the highest risk for shunt infection [42]. CSF protein was elevated in our cohort; unfortunately, prior studies have shown that CSF protein levels cannot distinguish aseptic post-surgical inflammation from shunt infection [42]. While hypoglycorrhachia occurred in our patients, this is again unable to differentiate post-surgical chemical meningitis from shunt infection [42]. In this population where infection most commonly occurs within 30 days of surgery, it is crucial to be able to differentiate post-surgical inflammation from shunt infection. Identification of more specific markers of infection is essential to improve our ability to identify these infections.

Pro-inflammatory mediators have been explored as a diagnostic strategy for bacterial meningitis. Multiple studies have demonstrated elevated levels of TNF- $\alpha$, IL-6, and IL-8 in the CSF of patients with bacterial meningitis, especially in the pediatric population $[22-25,29$, 30]. While there is promising data for TNF- $\alpha$, IL-6, and IL-8 as diagnostic biomarkers in meningitis, CSF shunt infections are a biofilm rather than planktonic infection which skews the host immune response $[10,12]$. Therefore, we examined cytokine/chemokine expression in the CSF of patients with gram-positive and gram-negative shunt infection.

The results of our study demonstrated similar levels of INF- $\gamma$, TNF- $\alpha$, IL- 6 , and IL- 8 in the CSF of patients with both gram-positive and gram-negative CSF shunt infections. This is consistent with results from Srinivasan et al. [25], which demonstrated elevated levels of these mediators in neonates with meningitis, $36 \%$ percent of which had a shunt infection. Our data as well as multiple studies in pediatric meningitis demonstrate that TNF- $\alpha$, IL- 6 , and IL- 8 are present in the CSF of patients with neurologic infection; however, these are likely not good markers for differentiating shunt infection from meningitis $[24,25,30]$.

In our cohort, there were trends of a distinct inflammatory response in gram-positive versus gram-negative shunt infections. CSF from patients with gram-positive infections had 

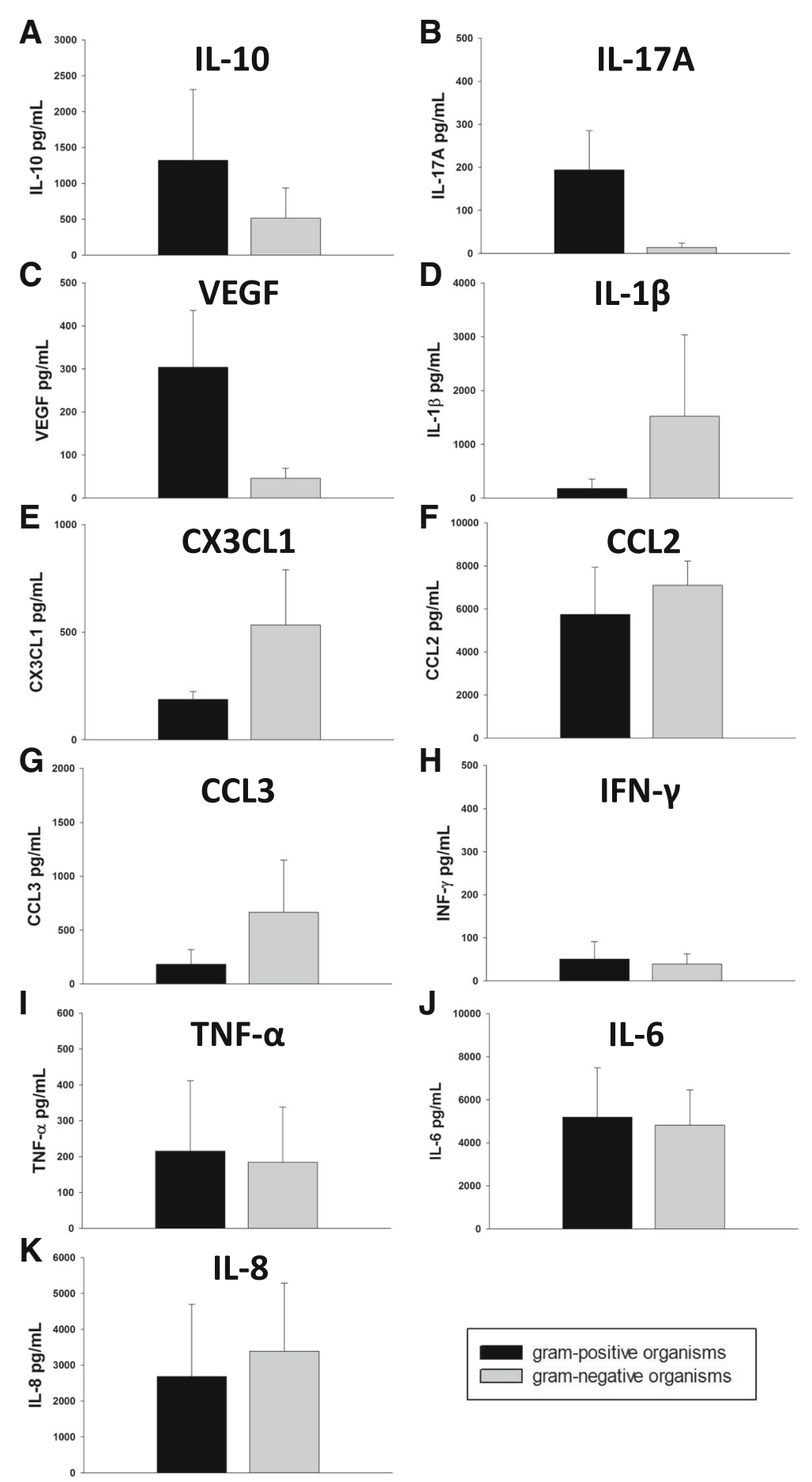

Fig. 1 CSF from patients with gram-positive infection has elevated levels of IL-10 (a), IL-17A (b), and VEGF (c) compared to gram-negative infections. Gram-negative shunt infections demonstrate increases in IL-1 $\beta(\mathbf{d}), \mathrm{Cx}_{3} \mathrm{CL}$, (E), CCL2 (f), and CCL3 (g). Gram-positive and gram-negative infections resulted in nearly equivalent levels of INF- $\gamma(\mathbf{h})$, TNF-a (i), IL-6 (j), and IL-8 (k). $n=3$ patients in gram-positive group, $n=2-4$ gramnegative group (2 samples had sufficient quantity for measurement of IFN- $\gamma$ and IL-17A)

higher levels of the anti-inflammatory cytokine IL-10 as well as IL-17A and VEGF. Those with gram-negative infection had higher levels of the pro-inflammatory cytokines IL-1 $\beta$, $\mathrm{CX}_{3} \mathrm{CL}_{1} \mathrm{CCL} 2$, and CCL3.
The increase in IL-10 in the gram-positive patients is consistent with a murine model of S. epidermidis CNS catheter infection [34]. This study demonstrated elevated levels of IL-10 in mice with $S$. epidermidis infected 
compared to sterile catheters [34]. IL-10 is an anti-inflammatory cytokine essential for controlling the production of pro-inflammatory cytokines [43, 44]. It is known to play a role in acute and chronic inflammation in the CNS, and in the setting of CNS catheter infection, its presence may curb the inflammatory environment $[34,45]$. Additionally, the presence of IL-10 has been highly associated with other types of staphylococcal infection. Rose et al. [46] demonstrated patients with elevated levels of IL-10 at the time of presentation with Staphylococcus aureus blood stream infection had higher mortality. Interestingly, two of the patients included in our cytokine analysis cohort had coagulase-negative staphylococcal infections. The increase in IL-10 may be dampening pro-inflammatory mediators, such as the elevated IL-17A and VEGF seen in these patients, and serving a neuroprotective role. This is being further evaluated in animal models of shunt infection.

In addition to increased IL-10, patients with gram-positive infections had higher levels of IL-17A and a neutrophil predominance in the CSF when compared to patients with gram-negative shunt infection. This is consistent with IL-17's role as an inducer of neutrophil chemokines, including IL-8, and IL-17's importance in a murine model of Staphylococcus aureus brain abscess [47, 48]. While shunt infections are biofilm rather than planktonic infections like brain abscess, the increased levels of IL-17A and neutrophil predominance in the CSF in our cohort suggest a Th17 response to gram-positive shunt infections in humans may predominate.

In addition to elevated IL-10 and IL-17A, patients with gram-positive shunt infection had elevated levels of VEGF, a potent mediator of vascular permeability associated with cerebral edema and neutrophil migration in the CNS [4951]. VEGF has been shown to be elevated in a rabbit model of Streptococcus pneumoniae meningitis as well as in tuberculous meningitis and other types of bacterial meningitis [52-54]. VEGF may be playing a role in the disruption of the blood-brain barrier in CNS infections, although it is unclear why VEGF is higher in patients with gram-positive shunt infection. This will be explored further in future studies.

Our ability to evaluate whether the gram-negative shunt infections have a Th1, Th2, or Th17 bias was limited due to sample availability. However, the data would suggest a potential skewing towards a Th1 immune response in gram-negative shunt infection with increased monocytes in the CSF of these patients compared to gram-positive infection as well as increase in IL-1 $\beta$ and a modest increase in INF- $\gamma$ in gram-negative infection. While there is limited data on the type of immune response gram-negative bacteria create in the CNS, studies have demonstrated that gram-negative elicit Th1 immune responses in models of intestinal inflammatory disorders $[55,56]$.
The CSF patterns reported in this study are likely reflective of differing immune pathways triggered by gram-positive versus gram-negative organisms [23]. Importantly, while chemokine and cytokine profiles have been evaluated as CSF biomarkers of meningitis, evaluation of these markers in the setting of shunt infection has been limited [25, 29, 31, 36]. Our results suggest that the distinct cytokine profiles elicited by gram-positive and gram-negative pathogens show promise as diagnostic tools for CNS shunt infections.

\section{Conclusions}

This pilot study is the first to characterize the CSF cytokine profile in patients with CSF shunt infection and has revealed distinct chemokine and cytokine profiles between gram-negative and gram-positive infections. While there is an interesting trend in the CSF cytokines that could greatly improve diagnosis of CSF shunt infection, there are several limitations with this pilot study. Epidemiologically, coagulase-negative staphylococci is the most common cause of CSF shunt infection, causing approximately two thirds of shunt infections, with Staphylococcus aureus as the second most common cause $[4,5,33]$. In contrast, this cohort of patients included a broad range of causative bacteria which did not follow typical epidemiologic patterns. However, our data demonstrate the elevation of chemokines and cytokines in the CSF of patients with shunt infection demonstrating the potential of CSF chemokine and cytokine measurement serving as a diagnostic strategy for shunt infection.

Secondly, in this small cohort, which was not large enough to determine statistical significance, clear trends of chemokines and cytokines were evident in gram-positive versus gram-negative shunt infection. These trends demonstrate a potential Th17-predominant immune response to gram-positive shunt infection and Th1-predominant response in gram-negative shunt infection. Additionally, due to the restrictions of available CSF, there is not a control population as CSF is not obtained from the shunts of well children as there is the possibility of iatrogenic infection. To address these limitations, we are currently developing a rat model of CSF shunt infection to further delineate CSF and serum inflammatory profiles in a controlled manner that will allow for analysis of postoperative versus infective changes. However, these pilot findings serve as a valuable introduction to the potential of CSF chemokines and cytokines as biomarkers for the diagnosis of shunt infection. By improving our ability to diagnose these infections, we can provide earlier effective therapy in a disease process which remains difficult to diagnose and treat.

\section{Abbreviations}

CCL2: Chemokine ligand 2; CCL3: Chemokine ligand 3; CNS: Central nervous system; CRP: C-reactive protein; CSF: Cerebrospinal fluid; $\mathrm{CX}_{3} \mathrm{CL}_{1}$ : Fractalkine; IL: Interleukin; INF- $\gamma$ : Interferon gamma; MCP-1: Monocyte chemoattractant 
protein-1; MMP-9: Matrix metallopeptidase-9; PCR: Polymerase chain reaction; sRAGE: Soluble receptor for advanced glycation end products; TNF-a: Tumor necrosis factor alpha; VEGF: Vascular endothelial growth factor; WBC: White blood cell

\section{Acknowledgements}

The authors thank the clinical microbiology laboratory at Children's Hospital and Medical Center for providing banked patient samples. We would also like to thank Tammy Kelian, PhD, for her assistance in the review and revision of this manuscript.

\section{Funding}

This work was funded by the Pediatric Research Fund at the University of Nebraska Medical Center.

\section{Availability of data and materials}

The datasets used and/or analyzed during the current study are available from the corresponding author on reasonable request.

\section{Authors' contributions}

GS designed the experiments; collected, analyzed, and interpreted the patient data; and was a major contributor in writing the manuscript. DS collected, analyzed, and interpreted the patient data. MB analyzed and interpreted the patient data. JS designed the experiments, analyzed and interpreted the patient data, and was a major contributor in writing the manuscript. All authors read and approved the final manuscript.

\section{Ethics approval and consent to participate}

This work was approved by the University of Nebraska Medical Center Institutional Review Board (502-15-EP, 020-15-EP).

\section{Consent for publication}

Not applicable

\section{Competing interests}

The authors declare that they have no competing interests.

\section{Publisher's Note}

Springer Nature remains neutral with regard to jurisdictional claims in published maps and institutional affiliations.

\section{Author details}

'Department of Pediatrics, University of Nebraska Medical Center, 982162 Nebraska Medical Center, Omaha, NE 68198-2162, USA. ²Department of Pediatrics, Children's Mercy Hospital, Kansas City, MO, USA. ${ }^{3}$ Department of Pediatrics, University of Arkansas for Medical Sciences, Little Rock, AR, USA.

\section{Received: 31 August 2018 Accepted: 2 January 2019}

\section{Published online: 09 January 2019}

\section{References}

1. Bondurant CP, Jimenez DF. Epidemiology of cerebrospinal fluid shunting. Pediatr Neurosurg. 1995;23:254-8 discussion 259.

2. Simon TD, Butler J, Whitlock KB, Browd SR, Holubkov R, Kestle JR, Kulkarni AV, Langley M, Limbrick DD Jr, Mayer-Hamblett N, Tamber M, Wellons JC 3rd, Whitehead WE, Riva-Cambrin J, Hydrocephalus Clinical Research Network. Risk factors for first cerebrospinal fluid shunt infection: findings from a multi-center prospective cohort study. J Pediatr. 2014;164:1462-8 e2.

3. Lee JK, Seok JY, Lee JH, Choi EH, Phi JH, Kim SK, Wang KC, Lee HJ. Incidence and risk factors of ventriculoperitoneal shunt infections in children: a study of 333 consecutive shunts in 6 years. J Korean Med Sci. 2012;27:1563.

4. Wells DL, Allen JM. Ventriculoperitoneal shunt infections in adult patients. AACN Adv Crit Care. 2013:24:6-12 quiz 13-4.

5. Odio C, McCracken GH Jr, Nelson JD. CSF shunt infections in pediatrics. A seven-year experience. Am J Dis Child. 1984;138:1103-8.

6. Prusseit J, Simon M, dB V, Heep A, Molitor E, Volz S, Simon A. Epidemiology, prevention and management of ventriculoperitoneal shunt infections in children. Pediatr Neurosurg. 2009:45:325-36.

7. Simon TD, Van Yserloo B, Nelson K, Gillespie D, Jensen R, McAllister JP 2nd Riva-Cambrin J, Stockmann C, Daly JA, Blaschke AJ. Use of quantitative 165 rRNA PCR to determine bacterial load does not augment conventional cerebrospinal fluid (CSF) cultures among children undergoing treatment for CSF shunt infection. Diagn Microbiol Infect Dis. 2014:78:188-95.

8. Fux CA, Quigley M, Worel AM, Post C, Zimmerli S, Ehrlich G, Veeh RH. Biofilm-related infections of cerebrospinal fluid shunts. Clin Microbiol Infect. 2006:12:331-7.

9. Fey PD, Olson ME. Current concepts in biofilm formation of Staphylococcus epidermidis. Future Microbiol. 2010;5:917-33.

10. Gries $C M$, Kielian T. Staphylococcal biofilms and immune polarization during prosthetic joint infection. J Am Acad Orthop Surg. 2017;25(Suppl 1):S20-4.

11. Ceri H, Olson ME, Stremick C, Read RR, Morck D, Buret A. The calgary biofilm device: new technology for rapid determination of antibiotic susceptibilities of bacterial biofilms. J Clin Microbiol. 1999;37:1771-6.

12. Heim CE, Vidlak D, Scherr TD, Kozel JA, Holzapfel M, Muirhead DE, Kielian T. Myeloid-derived suppressor cells contribute to Staphylococcus aureus orthopedic biofilm infection. J Immunol. 2014:192:3778-92.

13. Tunkel AR, Hasbun R, Bhimraj A, Byers K, Kaplan SL, Michael Scheld W, van de Beek D, Bleck TP, Garton HJ, Zunt JR. 2017 Infectious Diseases Society of America's clinical practice guidelines for healthcare-associated ventriculitis and meningitis. Clin Infect Dis. 2017:64:34-65.

14. Deutch S, Dahlberg D, Hedegaard J, Schmidt MB, Moller JK, Ostergaard L. Diagnosis of ventricular drainage-related bacterial meningitis by broadrange real-time polymerase chain reaction. Neurosurgery. 2007;61:306-11 discussion 311-2.

15. Garner JS, Jarvis WR, Emori TG, Horan TC, Hughes JM. CDC definitions for nosocomial infections, 1988. Am J Infect Control. 1988;16:128-40.

16. Harris KA, Hartley JC. Development of broad-range 165 rDNA PCR for use in the routine diagnostic clinical microbiology service. J Med Microbiol. 2003; 52:685-91.

17. Leber. Clinical microbiology procedures handbook. Washington, DC: ASM Press; 2016.

18. Rampini SK, Bloemberg GV, Keller PM, Buchler AC, Dollenmaier G, Speck RF, Bottger EC. Broad-range 16S rRNA gene polymerase chain reaction for diagnosis of culture-negative bacterial infections. Clin Infect Dis. 2011;53: 1245-51.

19. Simon TD, Pope CE, Browd SR, Ojemann JG, Riva-Cambrin J, MayerHamblett N, Rosenfeld M, Zerr DM, Hoffman L. Evaluation of microbial bacterial and fungal diversity in cerebrospinal fluid shunt infection. PLoS One. 2014:9:e83229.

20. Lan CC, Wong TT, Chen SJ, Liang ML, Tang RB. Early diagnosis of ventriculoperitoneal shunt infections and malfunctions in children with hydrocephalus. J Microbiol Immunol Infect. 2003;36:47-50.

21. Lolak S, Bunyaratavej K. C-reactive protein in prediction of ventriculoperitoneal shunt-related infection in high-risk patients. Surg Infect. 2013;14:192-5.

22. Mustafa MM. Role of tumor necrosis factor alpha (cachectin) in experimental and clinical bacterial meningitis. Pediatr Infect Dis J. 1989;8: 907-8.

23. Perdomo-Celis F, Torres MA, Ostos H, Gutierrez-Achury J, Molano V, Duran LF, Gonzalez G, Narvaez CF. Patterns of local and systemic cytokines in bacterial meningitis and its relation with severity and long-term sequelae. Biomark Insights. 2015;10:125-31.

24. Prasad R, Kapoor R, Srivastava R, Mishra OP, Singh TB. Cerebrospinal fluid TNF-alpha, IL-6, and IL-8 in children with bacterial meningitis. Pediatr Neurol. 2014;50:60-5.

25. Srinivasan L, Kilpatrick L, Shah SS, Abbasi S, Harris MC. Cerebrospinal fluid cytokines in the diagnosis of bacterial meningitis in infants. Pediatr Res. 2016;80:566-72.

26. Baggiolini M, Dewald B, Moser B. Interleukin-8 and related chemotactic cytokines--CXC and CC chemokines. Adv Immunol. 1994;55:97-179.

27. Waage A. Local production of tumor necrosis factor alpha, interleukin 1, and interleukin 6 in meningococcal meningitis. Relation to the inflammatory response. J Exp Med. 1989;170:1859-67.

28. van Furth AM, Roord JJ, van Furth R. Roles of proinflammatory and antiinflammatory cytokines in pathophysiology of bacterial meningitis and effect of adjunctive therapy. Infect Immun. 1996;64:4883-90.

29. Bociaga-Jasik M, Garlicki A, Ciesla A, Kalinowska-Nowak A, Sobczyk-Krupiarz I, Mach T. The diagnostic value of cytokine and nitric oxide concentrations in cerebrospinal fluid for the differential diagnosis of meningitis. Adv Med Sci. 2012;57:142-7.

30. Ye Q, Shao WX, Shang SQ, Shen HQ Chen XJ, Tang YM, Yu YL, Mao JH. Clinical value of assessing cytokine levels for the differential diagnosis of 
bacterial meningitis in a pediatric population. Medicine (Baltimore). 2016;95: e3222.

31. Grandgirard D, Gaumann R, Coulibaly B, Dangy JP, Sie A, Junghanss T, Schudel H, Pluschke G, Leib SL. The causative pathogen determines the inflammatory profile in cerebrospinal fluid and outcome in patients with bacterial meningitis. Mediat Inflamm. 2013;2013:312476.

32. Srinivasan L, Kilpatrick L, Shah SS, Abbasi S, Harris MC. Elevations of novel cytokines in bacterial meningitis in infants. PLoS One. 2018;13:e0181449.

33. Gutierrez-Murgas Y, Snowden JN. Ventricular shunt infections: immunopathogenesis and clinical management. J Neuroimmunol. 2014;276 $1-8$

34. Gutierrez-Murgas YM, Skar G, Ramirez D, Beaver M, Snowden JN. IL-10 plays an important role in the control of inflammation but not in the bacterial burden in S. epidermidis CNS catheter infection. J Neuroinflammation. 2016; 13:271

35. Snowden JN, Beaver M, Beenken K, Smeltzer M, Horswill AR, Kielian T. Staphylococcus aureus sarA regulates inflammation and colonization during central nervous system biofilm formation. PLoS One. 2013;8:e84089.

36. Ramos TN, Arynchyna AA, Blackburn TE, Barnum SR, Johnston JM. Soluble membrane attack complex is diagnostic for intraventricular shunt infection in children. JCl Insight. 2016;1:e87919.

37. Franke D, Block DR, Algeciras-Schimnich A, et al. Analysis of body fluids in clinical chemistry. 2nd ed. Wayne, Pennsylvania: Clinical and Laboratory Standards Institute; 2018.

38. Szamosi DI, Bautista JM, Cornbleet J, et al. Body fluid analysis for cellular composition; approved guideline. 1st ed. Wayne, Pennsylvania: Clinical and Laboratory Standards Institute; 2006.

39. Piatt JH Jr. Cerebrospinal fluid shunt failure: late is different from early. Pediatr Neurosurg. 1995;23:133-9.

40. Pirotte BJ, Lubansu A, Bruneau M, Loqa C, Van Cutsem N, Brotchi J. Sterile surgical technique for shunt placement reduces the shunt infection rate in children: preliminary analysis of a prospective protocol in 115 consecutive procedures. Childs Nerv Syst. 2007;23:1251-61.

41. Yousif TI, O'Reilly K, Nadeem M. Blood tests are not always helpful in predicting bacterial meningitis in children. Sudan J Paediatr. 2016;16:77-9.

42. Forgacs $P$, Geyer CA, Freidberg SR. Characterization of chemical meningitis after neurological surgery. Clin Infect Dis. 2001;32:179-85.

43. Ouyang W, Rutz S, Crellin NK, Valdez PA, Hymowitz SG. Regulation and functions of the IL-10 family of cytokines in inflammation and disease. Annu Rev Immunol. 2011;29:71-109.

44. Sabat R, Grutz G, Warszawska K, Kirsch S, Witte E, Wolk K, Geginat J. Biology of interleukin-10. Cytokine Growth Factor Rev. 2010;21:331-44.

45. Norden DM, Fenn AM, Dugan A, Godbout JP. TGFbeta produced by IL-10 redirected astrocytes attenuates microglial activation. Glia. 2014;62:881-95.

46. Rose WE, Shukla SK, Berti AD, Hayney MS, Henriquez KM, Ranzoni A, Cooper MA, Proctor RA, Nizet V, Sakoulas G. Increased endovascular Staphylococcus aureus inoculum is the link between elevated serum interleukin 10 concentrations and mortality in patients with bacteremia. Clin Infect Dis. 2017:64:1406-12

47. Bettelli E, Korn T, Oukka M, Kuchroo VK. Induction and effector functions of $\mathrm{T}(\mathrm{H}) 17$ cells. Nature. 2008;453:1051-7.

48. Ouyang W, Kolls JK, Zheng Y. The biological functions of T helper 17 cell effector cytokines in inflammation. Immunity. 2008:28:454-67.

49. Ferrara N, Gerber HP, LeCouter J. The biology of VEGF and its receptors. Nat Med. 2003:9:669-76

50. Moromizato Y, Stechschulte S, Miyamoto K, Murata T, Tsujikawa A, Joussen AM, Adamis AP. CD18 and ICAM-1-dependent corneal neovascularization and inflammation after limbal injury. Am J Pathol. 2000;157:1277-81.

51. Proescholdt MA, Heiss JD, Walbridge S, Muhlhauser J, Capogrossi MC Oldfield EH, Merrill MJ. Vascular endothelial growth factor (VEGF) modulates vascular permeability and inflammation in rat brain. J Neuropathol Exp Neurol. 1999;58:613-27.

52. Matsuyama W, Hashiguchi T, Umehara F, Matsuura E, Kawabata M, Arimura K, Maruyama I, Osame M. Expression of vascular endothelial growth factor in tuberculous meningitis. J Neurol Sci. 2001;186:75-9.

53. van der Flier M, Stockhammer G, Vonk GJ, Nikkels PG, van DiemenSteenvoorde RA, van der Vlist GJ, Rupert SW, Schmutzhard E, Gunsilius E, Gastl G, Hoepelman Al, Kimpen JL, Geelen SP. Vascular endothelial growth factor in bacterial meningitis: detection in cerebrospinal fluid and localization in postmortem brain. J Infect Dis. 2001:183:149-53.
54. van der Flier M, Coenjaerts FE, Mwinzi PN, Rijkers E, Ruyken M, Scharringa J, Kimpen $J$, Hoepelman Al, Geelen SP. Antibody neutralization of vascular endothelial growth factor (VEGF) fails to attenuate vascular permeability and brain edema in experimental pneumococcal meningitis. J Neuroimmunol. 2005;160:170-7.

55. Heimesaat MM, Bereswill S, Fischer A, Fuchs D, Struck D, Niebergall J, Jahn HK, Dunay IR, Moter A, Gescher DM, Schumann RR, Gobel UB, Liesenfeld O. Gram-negative bacteria aggravate murine small intestinal Th1-type immunopathology following oral infection with toxoplasma gondii. J Immunol. 2006;177:8785-95.

56. De Palma G, Cinova J, Stepankova R, Tuckova L, Sanz Y. Pivotal advance: bifidobacteria and gram-negative bacteria differentially influence immune responses in the proinflammatory milieu of celiac disease. J Leukoc Biol. 2010;87:765-78
Ready to submit your research? Choose BMC and benefit from:

- fast, convenient online submission

- thorough peer review by experienced researchers in your field

- rapid publication on acceptance

- support for research data, including large and complex data types

- gold Open Access which fosters wider collaboration and increased citations

- maximum visibility for your research: over $100 \mathrm{M}$ website views per year

At $\mathrm{BMC}$, research is always in progress.

Learn more biomedcentral.com/submissions 